\title{
Colitis ulcerosa complicated by malignant lymphoma: case report and analysis of published works
}

\author{
R Lenzen, F Borchard, H Lübke, G Strohmeyer
}

\begin{abstract}
A 51 year old woman with a two year history of ulcerative colitis developed a wide spread gastrointestinal non-Hodgkin's lymphoma of low grade malignancy (MALTlymphoma) involving upper and lower gastrointestinal tract, spleen, and bone marrow. After chemotherapy, clinical symptoms improved and lymphocytic infiltrates disappeared. Thirty nine cases of ulcerative colitis and 22 cases of Crohn's disease complicated by gastrointestinal lymphomas reported in published works are reviewed. In inflammatory bowel diseases any dense lymphocytic infiltrates seen in biopsy specimens obtained from ulcerative colitis or Crohn's disease should be assessed to exclude gastrointestinal lymphoma.

(Gut 1995; 36: 306-310)
\end{abstract}

Keywords: colitis ulcerosa, non-Hodgkin's lymphoma.

Although colonic carcinoma is the major longterm complication of ulcerative colitis, primary colonic lymphoma has also been shown to be associated with ulcerative colitis. As the clinical symptoms of chronic inflammatory bowel disease and malignant lymphoma of the large bowel can be very similar, diagnosis of lymphoma can be masked and correct treatment may be delayed. We report a case of a

Department of Medicine, Division of Gastroenterology

R Lenzen

H Lübke

G Strohmeyer

Department of Pathology, HeinrichHeine-University, Düsseldorf, Germany F Borchard

Correspondence to: Dr R Lenzen, Department of Medicine, Division of Gastroenterology, Rudolf Virchow University, Augustenburger Platz 1 13353 Berlin 65, Germany.

Accepted for publication 29 April 1994
Figure 1: Endoscopic view of the colon with completely disappeared vascular pattern, highly increased vulnerability of mucosa, and slight mucosal damage representing an endoscopy index of 8 indicating distinct inflammatory activity according to Rachmilewitz. ${ }^{65}$

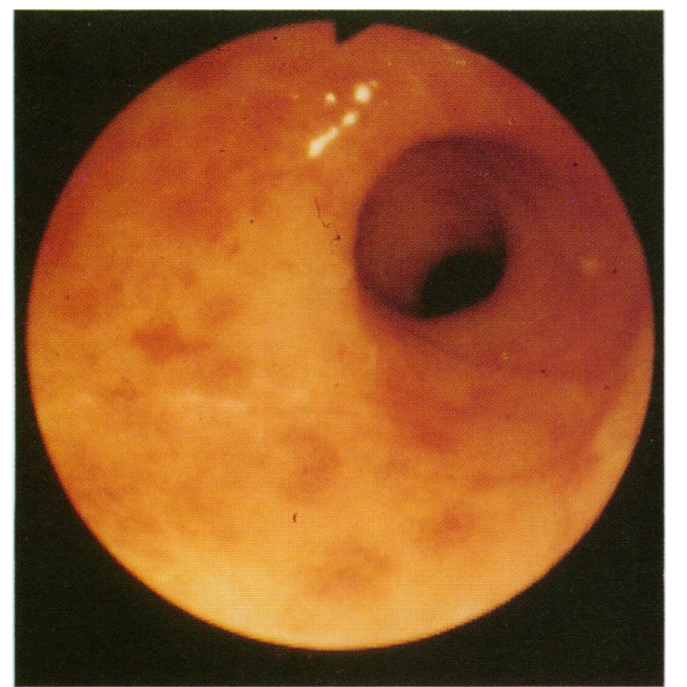

patient suffering from ulcerative colitis for more than two years when malignant lymphoma of the colon developed. The diagnosis was made after treatment failure of the colitis with corticosteroids, azathioprine, and sulphasalazine.

\section{Case report}

A 51 year old woman suffering from ulcerative colitis since 1989 was transferred to our hospital in 1991 because of ineffective longterm treatment with corticosteroids, azathioprine, and sulphasalazine. First endoscopy of the colon and histological examination in 1989 showed chronic inflammatory bowel disease with typical signs of ulcerative colitis (Figs 1 and 2) involving the entire colon and the terminal ileum. Different therapeutic strategies including total parenteral or enteral nutrition had not improved the symptoms, which were dominated by $10-15$ bloody stools a day.

When we saw the patient in 1991, she presented with a slightly painful abdomen with normal peristalsis, no superficial lymphadenopathy, no hepatosplenomegaly. Laboratory examinations showed mild inflammatory

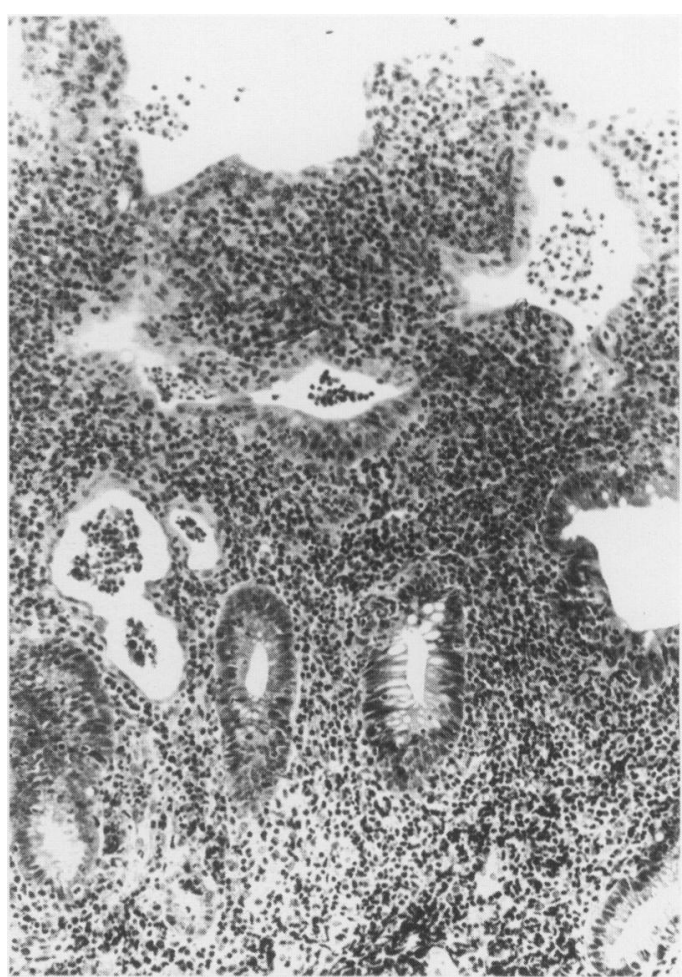

Figure 2: Typical ulcerative colitis with crypt distortion, crypt abscesses, and irregular surface. Haematoxylin and eosin, original magnification $\times 225$. 


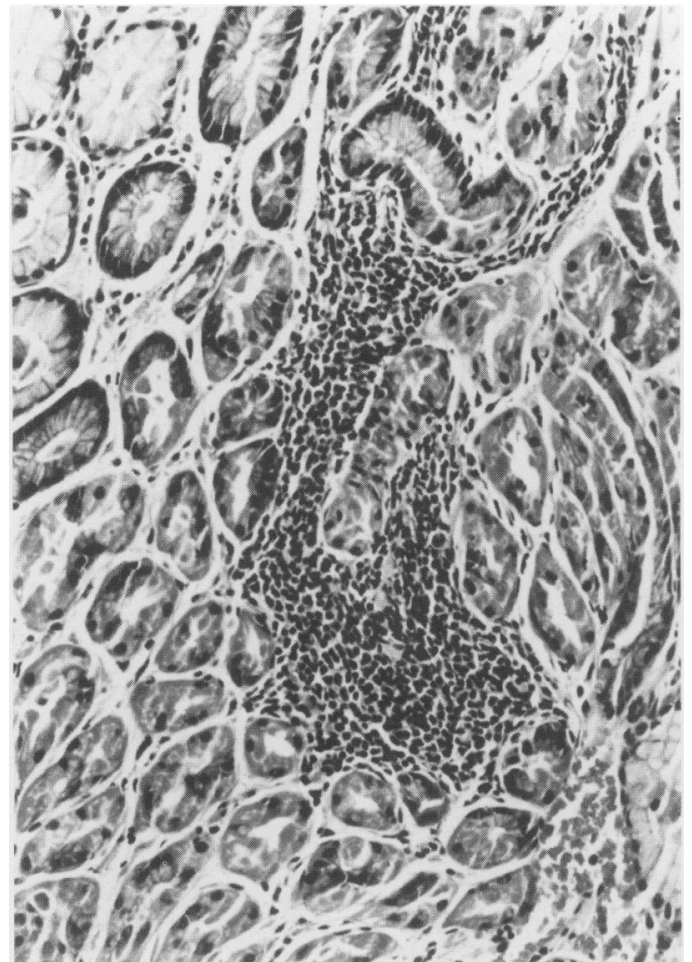

Figure 3: Dense, sharply limited lymphocytic infiltrate in the upper half of an otherwise normal gastric body mucosa. Haematoxylin and eosin, original magnification $\times 95$.

activity, anaemia, normal total and differential white blood cell counts, and normal immunoglobulin values. Repeated stool cultures were negative. A chest $x$ ray showed no evidence of lymphadenopathy. Abdominal ultrasonography and computed tomography showed slightly enlarged spleen and multiple lymph nodes up to $1 \mathrm{~cm}$ diameter. In upper endoscopy we only saw a small duodenal ulcer and mild inflammation of the gastric mucosa.

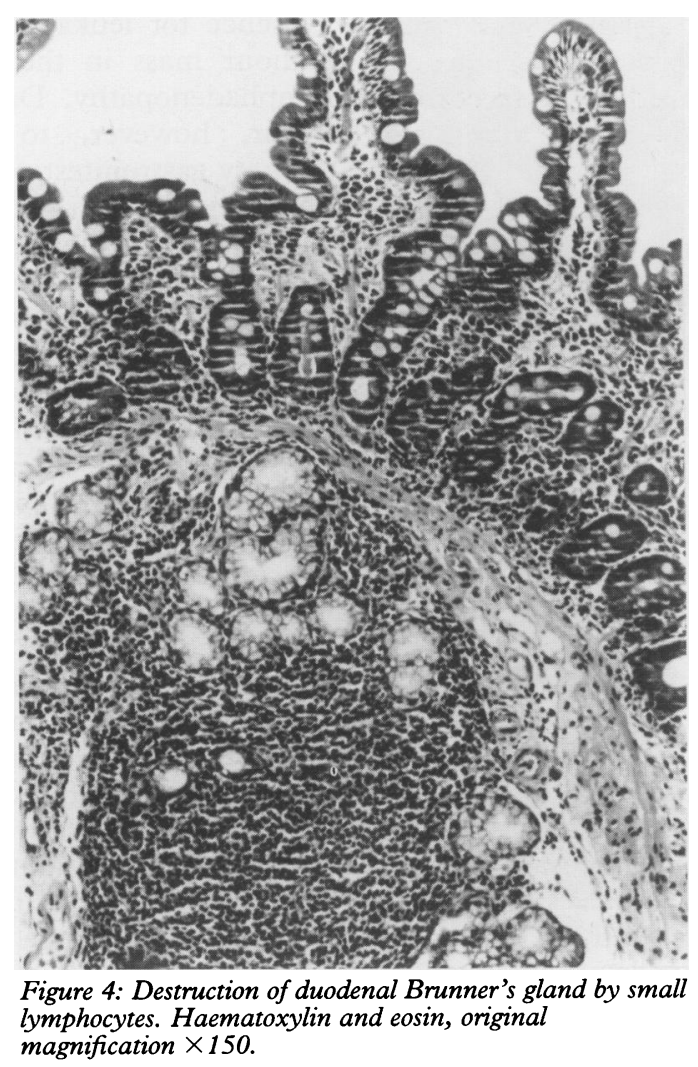

Colonoscopy showed a mild form of acute ulcerative colitis. Histological examination of the stomach and duodenal biopsy specimens showed not only typical polymorphonuclear inflammatory infiltration, but also distinct lymphocytic infiltration (Figs 3 and 4), which was even more evident in the colonic biopsy specimens (Fig 5A). In all sections the lymphocytic infiltration invaded the mucosa forming lymphoepithelial lesions and destroying the mucosal glands, typical evidence for the presence of primary gastrointestinal malignant lymphoma of MALT type (Fig 5B). Cells showed typical cleaved nuclei reminiscent of centrocytic cells (Fig 5C). Characteristic signs for acute ulcerative colitis were no longer detectable. Further immunocytochemistry confirmed this to be a B cell lymphoma (Fig 6). Histological examination of the bone marrow showed invasion of the malignant lymphoma, which had already led to a $40 \%$ suppression of bone marrow cells (Fig 7).

Summarising the results, our patient had developed a low grade B cell non-Hodgkin's lymphoma involving the upper and lower gastrointestinal tract and the bone marrow that is, stage IV. The enlargement of abdominal lymph nodes and spleen was probably also caused by distant lymphoma spread.

\section{TREATMENT}

The patient received chemotherapy according to the CVP protocol: cyclophosphamide $400 \mathrm{mg} / \mathrm{m}^{2}$, vincristine $1.4 \mathrm{mg} / \mathrm{m}^{2}$, prednisone $60 \mathrm{mg} / \mathrm{m}^{2}$. After three courses, there was a decrease in diarrhoea from 10 to 5 stools daily with no blood contamination. Continuation of the chemotherapy for another three courses did not result in any further decrease in stool frequency. Repeated colonoscopy and bone marrow investigation, however, showed a progressive reduction of the lymphocytic infiltration. After chemotherapy had ended, the colon endoscopically showed typical changes as seen after long standing chronic inflammation of the colon with reduced haustration, but no evidence for acute disorder. Histologically, the malignant lymphoma was no longer present. Bone marrow was also free of lymphocytic infiltration. Abdominal computed tomography showed normal size of spleen and normal lymph nodes.

\section{Discussion}

Primary gastrointestinal lymphomas occur between 1 and $4 \%$ of all gastrointestinal malignancies. ${ }^{1}$ The gastrointestinal tract is the commonest site of extranodal lymphomas. ${ }^{2}$ In western populations, the stomach is most commonly involved, while colorectal lymphoma comprises between 10 and $20 \%$ of primary gut lymphomas in the larger published series. $^{13-6}$ This fraction, however, may be reduced to $3 \%$ if ileocaecal tumours are excluded. ${ }^{7}$ Most of the tumours show characteristic histological and immunohistochemical features: the B cell tumours are composed of a polymorphic population of centrocytic like 


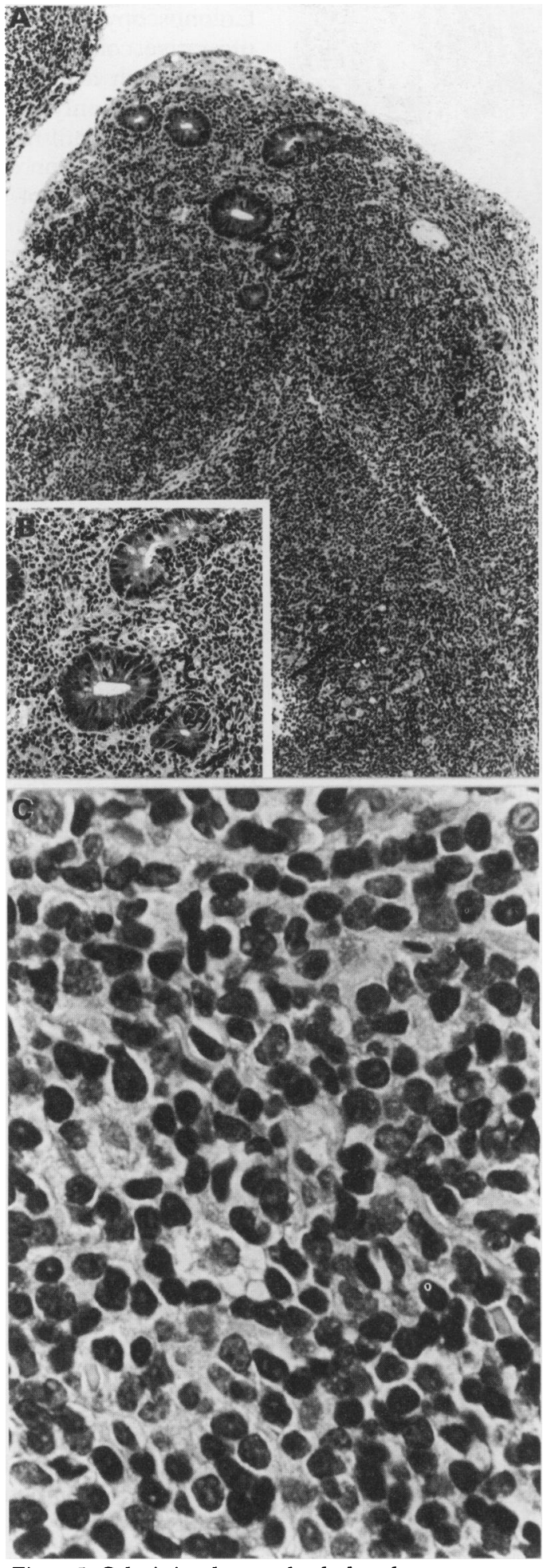

Figure 5: Colonic involvement by the lymphoma.

(A) Replacement of the crypts by the aggressive lymphoid infiltrate. Haematoxylin and eosin, original magnification $\times 95$. (B) Inset: enlargement of the group of crypts shows two glands invaded by lymphoid cells (so called lymphoepithelial lesions). Haematoxylin and eosin, origina magnification $\times 230$. (C) High power enlargement of the lymphoma cells: small lymphocytic cells with partly cleaved, centrocytoid nucleus. Haematoxylin and eosin, original magnification $\times 600$.

cells, plasmacytoid cells, and blast cells. Isaacson defined these neoplasmas as 'malignant lymphomas arising in mucosa associated lymphoid tissue - MALToma' ${ }^{89}$ An important and distinctive feature of these lymphoma cells is the tendency to invade mucosal epithelium and form characteristic lymphoepithelial lesions. Often these centrocyte like cells are

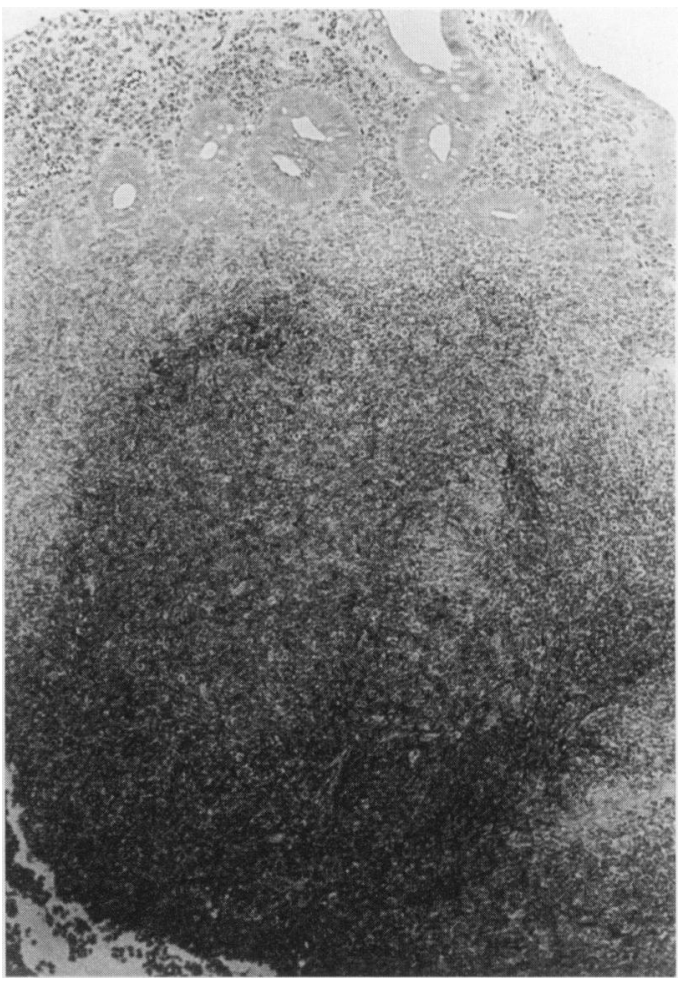

Figure 6: Immunohistochemistry. Nodular infiltration of the mucosa without formation of germinal centre by $B$ lymphocytes showing the phenotype CD20+ (L26+), $P A P$ method, original magnification $\times 95$.

present as clusters, both intraepithelially and intraluminally and obliterate partially the mucosal glands. ${ }^{10}$

To distinguish between primary and secondary gastrointestinal lymphoma, the definition of primary gastrointestinal lymphoma by Dawson $^{11}$ is quite applicable, which consists of a normal chest $x$ ray, no evidence of hepatosplenomegaly or superficial lymphadenopathy, a normal white blood cell count (that is, no evidence for leukaemia), and a predominant tumour mass in the bowel with only local lymphadenopathy. Diagnostic problems may occur, however, to discriminate between primary gastrointestinal lymphoma, which has generalised and nodal lymphoma, with secondary gastrointestinal manifestation. This case fulfils these criteria, except for the mild splenomegaly and bone marrow infiltration, which was caused by distant spread.

The combination of gastrointestinal malignancy and chronic inflammatory bowel disease is of increasing interest. It is already well known that, after 25-30 years of ulcerative colitis, the cumulative risk of developing cancer is about $10 \% .^{12-14}$ Adenocarcinoma complicating Crohn's disease is increasingly recognised, especially in the small intestine. ${ }^{15}$ The nature of the relation between inflammatory bowel disease and intestinal lymphoma, however, is less certain. The first instance of this association is Barken in 1927 who reported two cases in ulcerative colitis with malignant lymphoma. ${ }^{16}$ To date, there are 26 publications ${ }^{16-41}$ reporting 39 cases of nonHodgkin's lymphoma (35 cases) or Hodgkin's lymphoma (four cases 21252736 ) complicating ulcerative colitis. Four of these case reports even describe the additional occurrence of 


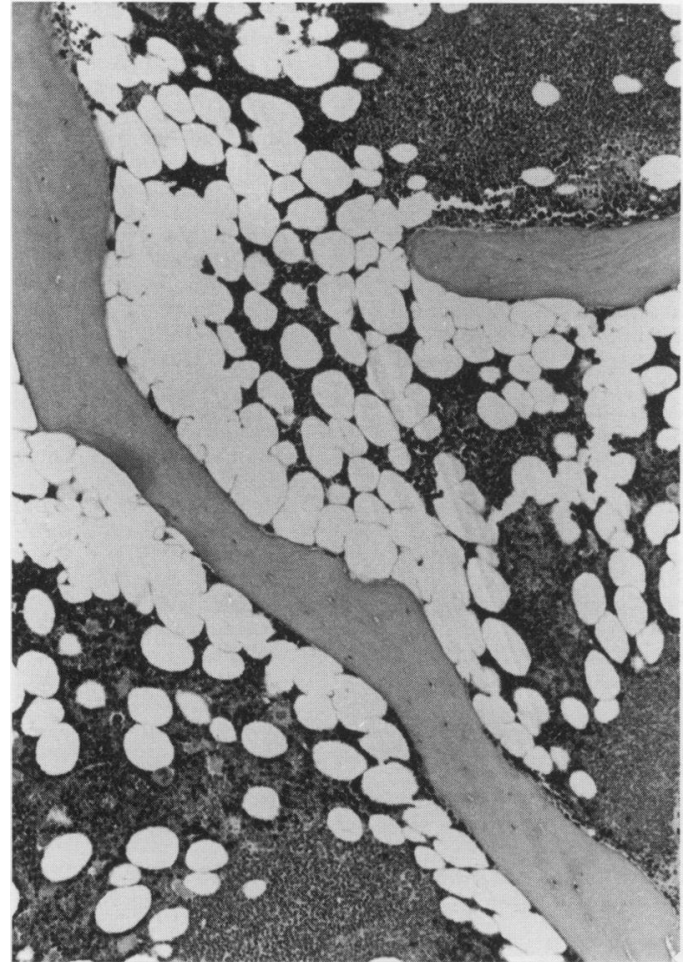

Figure 7: Nodular infiltration of the bone marrow by non-Hodgkin's lymphoma of low grade malignancy. Chloracetatesterase-Leder-stain, original magnification $\times 95$.

colon cancer. ${ }^{1725} 3134$ Most lymphomas in ulcerative colitis, like carcinoma in colitis, arose on the basis of extensive long standing disease (mean duration of colitis at the time of lymphoma diagnosis 12 years; mean age at lymphoma diagnosis $50 \cdot 3$ years). ${ }^{39}$ They differ from sporadic colorectal lymphoma in a number of ways 37 38: colitis associated lymphomas are more often multiple (38\% $v 10 \%$, except for malignant lymphomatous polyposis), left sided (compared with the caecal predominance in sporadic lymphoma), high grade $(80 \% v 35 \%)$ in an advanced stage at diagnosis. This case does not entirely match these criteria, especially as a long history of ulcerative colitis before the lymphoma is lacking.

The small numbers of reported cases make it difficult to prove a definite association between ulcerative colitis and colonic lymphoma, although various mechanisms of pathogenesis have been postulated. These include repeated episodes of prolonged stimuli of the MALT tissue and lymphoid hyperplasia. ${ }^{19} 21$

There are fewer reports about an association with gastrointestinal lymphoma with regard to Crohn's disease. We found 20 publications describing 25 cases of this combination, ${ }^{36} 39$ 42-59 18 non-Hodgkin's lymphoma, and four Hodgkin's lymphoma. 36505253 In these cases, it is even more difficult to prove an association between the two diseases. Yet, there are some findings supporting this concept: all reported tumours have arisen at sites of active inflammatory bowel disease and the comparative incidence of lymphoma in different parts of the gut seems to reflect the incidencé of Crohn's disease. Furthermore, it is interesting to note that Crohn's tissue homogenates have been reported to induce $\mathbf{B}$ cell lymphomas in athymic mice suggesting, at least in experimental animals, that a link between Crohn's disease, immunosuppression, and malignant lymphoma exists. ${ }^{6061}$ Another factor to be considered is the prolonged use of corticosteroids and azathioprine. A convincing relation has been established between immunosuppressive drug treatment and an increased incidence of malignant tumours in patients after organ transplantation. ${ }^{62}$ Recently, an increasing number of cases have been reported in homosexuals in association with the acquired immune deficiency syndrome (AIDS). ${ }^{63} 64$

Before starting any treatment, profound staging is required. This includes upper and lower endoscopy with multiple biopsy specimens from all different parts, contrast radiography of the small intestine, cervical, thoracic and abdominal computed tomography, bone marrow cytology and histology, scintigraphy of the skeleton, endosonography, and in addition liver biopsy.

Treatment of inflammatory bowel disease combined with gastrointestinal lymphoma follows primarily the guidelines of lymphoma treatment: at stage I and II surgery either alone or in combination with radiotherapy should be performed. Chemotherapy should be the primary treatment for cases of malignant lymphomatous polyposis as this type of lymphoma is usually widespread throughout the gastrointestinal tract. Radiotherapy or chemotherapy, or both may also be of use for cases with advanced stage and high grade lymphomas. ${ }^{33}$ Yet, prognosis seems to be poor. ${ }^{32} 33$ Adenocarcinoma combined with chronic inflammatory bowel disease obviously has a better survival than colorectal lymphoma. ${ }^{33}$

In conclusion, malignant lymphoma of the bowel is a rare but significant complication of inflammatory bowel disease, apparently being more common in chronic ulcerative colitis than in Crohn's disease. It is quite conceivable that the changed lymphoid populations in inflammatory bowel disease represents the clones in which lymphoma arises. Therefore, it is important to evaluate any lymphocytic infiltrate seen in a biopsy specimen, especially when anti-inflammatory treatment seems to be ineffective.

1 Loehr WJ, Mujahed Z, Zahn FD, Gray GF, Thornbjarson B. Primary lymphoma of the gastrointestinal tract: a review of 100 cases. Ann Surg 1969; 170: 232-8.

2 Freeman C, Berg JW, Cutler SJ. Occurrence and prognosis of extranodal lymphomas. Cancer 1972; 29: 252-60.

3 Henry K, Farrer-Brown G. Primary lymphomas of the gastrointestinal tract. 1. Plasma cell tumours. Histopathology 1977; 1: 53-76.

4 Lewin KJ, Ranchod M, Dorfman RF. Lymphomas of the gastrointestinal tract. A study of 117 cases, presenting
with gastrointestinal disease. Cancer 1978; 42: 693-707. 5 Contreary K, Nance FC, Becker WF. Primary lymphoma of the gastrointestinal tract. Ann Surg 1980; 191: 593-8.

6 the gastrointestinal tract. Ann Surg 1980; 191: 593-8. Dragosics B, Bauer P, Radaszikiewicz T. Primary gastro-
intestinal non-Hodgkin's lymphomas. A retrospective intestinal non-Hodgkin's lymphomas. A retrospective
clinico-pathological study of 150 cases. Cancer 1985; 55: clinico-pathol.

7 Isaacson PG, Wright DH, Judd MA, Mepham BL. Primary gastrointestinal lymphomas: a classification of 66 cases. Cancer 1979; 43: 1805-19.

8 Isaacson PG, Wright DH. Extranodal malignant lymphoma arising from mucosa associated lymphoid tissue. Cancer 1984; 53: 2515-24. 
9 Myhre M, Isaacson PG. Primary B-cell gastric lymphoma a reassessment of its histogenesis. $\mathcal{F}$ Pathol 1987; 152: $1-11$.

10 Isaacson PG, Spencer J. Malignant lymphoma of mucosaassociated lymphoid tissue. Histopathology 1987; 11: 445-62.

11 Dawson IMP, Cornes JS, Morson BC. Primary malignant lymphoid tumours of the gastrointestinal tract. $\mathrm{Br} \mathcal{F}$ Surg 1961; 49: 80-9.

12 Ekbom A, Helmick E, Zack M, Adami HO. Ulcerative colitis and colorectal cancer. A population-based study. N Engl f Med 1990; 323: 1228-33.

13 Gilat T, Fireman Z, Grossman A, Hacohen D, Kadish U, Ron E, et al. Colorectal cancer in patients with ulcerative colitis. A population study in central Israel. Gastroenterology 1988; 94: 870-7.

14 Katzka I, Brody RS, Morris E, Katz S. Assessment of colorectal cancer risk in patients with ulcerative colitis. Experience from a private practice. Gastroenterology 1983; 85: $22-9$.

15 Petras RE, Mir-Madjlessi SH, Farmer RG. Crohn's disease and intestinal carcinoma. A report of 11 cases with emphasis on associated epithelial dysplasia. Gastroenterology 1987; 93: 1307-11.

16 Bargen JA. Chronic ulcerative colitis associated with malignant disease. Arch Surg 1928; 17: 561-76.

17 Catell RB, Boehme EJ. The importance of malignant degeneration as complication of chronic ulcerative colitis. Gastroenterology 1947; 8: 695-710.

18 Warren KW. Malignant lymphoma of the duodenum, small intestine and colon. Surg Clin North Am 1959; 39: 725-35.

19 Cornes JS, Smith JC, Southwood WF. Lymphosarcoma in chronic ulcerative colitis with report of two cases. Br f Surg 1961; 49: 50-3

20 Delannoy E, Buffin RP. Reticulosarcome sur rectocolite hemorragique (colite ulcerative). Presse Med 1969; 70: 1006-7.

21 Sataline LR, Mobley EM, Kirkham W. Ulcerative colitis complicated by colonic lymphoma. Gastroenterology 1963; 44: 342-7.

22 Walker FC, Weaver JP. Lymphosarcoma in ulcerative colitis. Br f Surg 1964; 51: 475-7.

23 Meadows R. Hodgkin's disease of the colon presenting as disseminated sclerosis with associated ulcerative colitis. Aust NZ F Surg 1965; 35: 80-2.

24 Wychulis AR, Beahrs OH, Woolner LB. Malignant lymphoma of the colon. A study of 69 cases. Arch Surg 1966; 93: 215-25.

25 Nugent FW, Zuberi S, Bulan MB, Legg MA. Colonic lymphoma in ulcerative colitis: a report of four cases. Lahey Clinic Foundation Bulletin 1972; 21: 104-11.

26 Parikh NK, Shah PM, Patel SM, Chandra DD. Colonic lymphoma in ulcerative colitis (a case report). $\mathcal{f}$ Assoc lymphoma in ulcerative colitis (a

27 Vieta JO, Delgado GE. Chronic ulcerative colitis complicated by colonic lymphoma: report of a case. Dis Colon Rectum 1976; 19: 56-62.

28 Renton P, Blackshaw AJ. Colonic lymphoma complicating ulcerative colitis. Br $\mathcal{F}$ Surg 1976; 63: 542-5.

29 Wagonfield JB, Platz CE, Fishman FL, Sibley RK, Kirsner JB. Multicentric colonic lymphoma complicating ulcerative colitis. Am F Dig Dis 1976; 22: 502-8.

30 Emanuel JC, Isbister WH. Chronic mucosal ulcerative colitis with malignant lymphoma: report of a case. Colitis with malignant lymph

31 Bashiti HO, Kraus KT. Histiocytic lymphoma in chronic ulcerative colitis. Cancer 1980; 46: 1695-700.

32 Barki Y, Boult I. Two uncommon malignancies complicating chronic ulcerative colitis. $\mathcal{f}$ Can Assoc Radiol 1981; 32: 136-7.

33 Bartolo D, Goepel JR, Parsons MA. Rectal malignant lymphoma in chronic ulcerative colitis. Gut 1982; 23: 164-8.

34 Hope-Ross M, Magee DJ, O'Donoghue DP, Murphy JJ. Ulcerative colitis complicated by lymphoma and adenocarcinoma. Br $\mathcal{F}$ Surg 1985; 72: 22.

35 Baker D, Chiprut RO, Rimer D, Lewin KJ, Rosenberg MZ. Colonic lymphoma in ulcerative colitis. $f$ Clin Gastroenterol 1985; 7: 379-86.

36 Greenstein AJ, Gennuso R, Sachar DB, Heimann T, Smith $\mathrm{H}$, Janowith $\mathrm{HD}$, et al. Extraintestinal cancers in inflamH, Janowith HD, et al. Extraintestinal cancers in

37 Richards MA. Lymphoma of the colon and rectum. Postgrad Med $\mathcal{F}$ 1986; 62: 615-20.
38 Shepherd NA, Hall PA, Coates PJ, Levison DA. Primary malignant lymphoma of the colon and rectum. A histopathological and immunohistochemical analysis of 45 cases with clinicopatholigical correlations. Histopathology 1988; 12: 235-52.

39 Shepherd NA, Hall PA, Williams GT, Codling BW, Jones EL, Levison DA, et al. Primary malignant lymphoma of the large intestine complicating chronic inflammatory bowel disease. Histopathology 1989; 15: 325-37.

40 Abulafi AM, Fiddian MCh. Malignant lymphoma in ulcerative colitis. Dis Colon Rectum 1990; 33: 615-8.

41 Teare JP, Greenfield SM, Slater S. Rectal lymphoma after colectomy for ulcerative colitis. Gut 1992; 33: 138-9.

42 Hughes R. Reticulum cell sarcoma: a case possibly originating in regional enteritis. Ann Surg 1955; 21: 770-3

43 Case records of the Massachusetts General Hospital: Case 43292. N Engl f Med 1957; 257: 135-41.

44 Wyburn-Mason R. A new protozoan: its relation to malignant and other diseases. Springfield: Charles C Thomas, 1964 49-50.

45 Wyburn-Mason R. Crohn's disease and carcinoma of the colon. BMF 1968; 2: 697 .

46 Fielding JF, Prior P, Waterhouse JA. Malignancy in Crohn's disease. Scand $\mathcal{F}$ Gastroenterol 1972; 7: 3-7.

47 Codling BW, Keighley MRB, Slaney G. Hodgkin's disease complicating Crohn's disease. Surgery 1977; 82: 625-8. 48 Collins WJ. Malignant lymphoma complicating regional enteritis: case report and review of the literature. Am f Gastroenterol 1977; 68: 177-81.

49 Lee GB, Smith PM, Seal RME. Lymphosarcoma in Crohn's disease: report of a case. Dis Colon Rectum 1977; 20: 351-4.

50 Hecker R, Sheers R, Thomas D. Hodgkin's disease as complication of Crohn's disease. Med f Aust 1978; 2: 603.

51 Gyde SM, Prior P, Macartney JC. Malignancy in Crohn's disease. Gut 1980; 21: 1024-9.

52 Morrison PD, Whittaker M. A case of Hodgkin's disease complicating Crohn's disease. Clin Oncol 1982; 8: 271-2.

53 Shaw JHF, Mulvaney N. Hodgkin's lymphoma: a complication of small bowel Crohn's disease. Aust NZ F Surg 1982; 52: 34-6.

54 Glick SN, Teplick SK, Goodman LR. Development of lymphoma in patients with Crohn's disease. Radiology 1984; 153: 337-9.

55 Kwee WS, Wils JAMJ, van den Tweel JG. Malignant lymphoma, immunoblastic with plasmacytic differentiation, complicating Crohn's disease. Histopathology 1985; 9 1115-20.

56 Kini SU, Pai PK, Rao PK, Kini AU. Primary gastric lymphoma associated with Crohn's disease of the stomach. Am 7 Gastroenterol 1986; 81: 23-5.

57 Robertson EJ, Al-Kaisi NK, Vareska GJ, Ponsky JL. Plasmacytoma of the ileum complicating Crohn's disease: report of a case and review of the literature. Surgery 1986; 100: $916-23$

58 Williams JG, Williams GT, Gough J, Jasani B, Young HL. Primary malignant lymphoma of the large intestine. Coloproctology 1988; 10: 238-43.

59 Rosenthal E, Ben-Arieh J, Benderly A, Etzioni A, Pery M, Geiger S. Lymphoma complicating Crohn's disease in a child. Gastroenterohepatoloski Arhiv 1990; 9: 130-4.

60 Das KM, Valenzuela I, Morecki R. Crohn disease lymph node homogenates produce murine lymphoma in athymic mice. Proc Natl Acad Sci USA 1980; 77: 588-92.

mice. Proc Natl Acad Sci USA 1980; 77: 588-92.
61 Williams SE, Valenzuela I, Kadish AS, Das KM lymphoma in athymic nude mice by tissue filtrates of lymphoma in athymic nude mice by tissue filtrates of
Crohn's disease patients. $\mathcal{F}$ Lab Clin Med 1982; 99: Crohn's

62 Ziegler JL, Beckstead JA, Volberding PA, Abrams DI, Levine AH, Lukes RJ, et al. Non-Hodgkin's lymphoma in 90 homosexual men. Relation to generalized lymphadenopathy and the acquired immunodeficiency syndrome. N Engl f Med 1984; 311: 565-70.

63 Burkes RL, Meyer PR, Gill PS, Parker JW, Rashed S, Levine AM. Rectal lymphoma in homosexual men. Arch Intern Med 1986; 146: 913-5.

64 Lee MH, Waxman M, Gillooley JF. Primary malignant lymphoma of the anorectum in homosexual men. lymphoma of the anorectum in
Dis Colon Rectum 1986; 29: 413-6.

65 Rachmilewitz R. Coated mesalazine (5-aminosalicylic acid) versus sulphasalazine in the treatment of active ulcerative colitis: a randomised trial. $B M \mathcal{F} 1989 ; 298: 82-6$. 